\title{
The Perspective of Physical Education and Sport Teachers on the Participation of Parents of Students with Disability
}

\author{
Dena Widyawan* \\ Department Pendidikan Jasmani Kesehatan dan Rekreasi \\ STKIP Situs Banten \\ Serang, Indonesia \\ *dena.widyawan@stkipsitusbanten.ac.id
}

\author{
Amung Ma'mun, Berliana, Yudy Hendrayana \\ Departemen Pendidikan Olahraga \\ School of Postgraduate Studies \\ Universitas Pendidikan Indonesia \\ Bandung, Indonesia
}

\begin{abstract}
Besides exploring the phenomenon of participation of parents of students with disability in special need schools, it is significant to gain the perspective of physical education and sport teachers because a teacher is the influential figure in the environment who interacts directly with students. In addition, students with disability are obliged to participate in physical education and sport lesson. Accordingly, it is fundamental to gain the perspective from physical education and sport teachers as the learning facilitator. For that reason, the objective of this preliminary research was to explore the meaning of the teacher that was constructed from parents' participation in physical education and sport learning. Therefore, this research highlighted the understandings of: first, the notion of teachers in parents' participation; second, the importance of teacher in physical education and sport learning process and their involvements in parents' participation; third, teachers' experiences in physical education and sport learning and the relation with parents of students with disability.
\end{abstract}

Keywords: physical education, teachers' perspective, participation parents, disability

\section{INTRODUCTION}

A previous study was done and guided by question on how the participation of parents of student with the disability represented on physical education and sport. The research was done because of the researcher interest on participation of parents of student with the disability phenomenon. Exploring the phenomenon of parents' participation in the context of special needs school, it is important to obtain the perspective of physical education and sport teachers since teachers are the important figure in the environment that interact with the students [1]. Furthermore, the students with disability are obliged to participate in physical education and sport lesson, therefore the perspective from the teachers as learning facilitator is needed. For that reason, the objective of this preliminary study is to explore the mean of teacher of physical education and sport in special need school that is developed by the participation of parents in physical education and sport learning.

Thus, this research specifically aims to gather the understanding on:
- the notion of teachers on parents' participation in physical education and sport lesson

- the importance of teachers in physical education learning process in its relation to parents' participation, and

- The teachers' experience on the physical education and sport learning process and the relation of teachers and parents of students with disability.

\section{ECOLOGICAL SYSTEMS THEORY}

Ecological systems theory "focuses on the importance of interactions within and between life contexts (e.g., work, school, family, etc.)" [2]. four systems comprise the theory: (a) microsystem, (b) mesosystem (c) ecosystem and (d) macrosystem. These environmental systems represent different spaces whereby interaction occurs [3]. Further the nature of the interaction at one level is influenced by events at other levels [4].

\section{A. Microsystem}

The microsystem "represents an individual's immediate context including associated roles, actors, and environmental characteristics" [5]. At this level, the child has a reciprocal relationship with the environment. Child's biological and social behaviors (e.g., disability) influence the parent's behavior (e.g., involvement in school) as well as the parent as a primary caregiver in the family influences the child's behavior [6].

\section{B. Mesosystem}

The mesosystem refers to the connection between the child's microsystems (e.g., parents and teachers). A child's learning progress is influenced not only by activities taken place in classes but also supported by his/her parent participation in school. If there is a link between home (parent) and school (teacher), the child's development is likely influenced by their relationships [6]. Bronfenbrenner [3] further classified the interconnections between home and school settings as (a) multisetting participation where the child is engaging in (home and school); (b) indirect relation 
established by the connection between home and school (parents and teachers interactions), (c) inter setting communications where messages are transmitted from one setting to the other (school newsletter, progress report), and (d) inter setting knowledge where information or experiences are obtained from others [4].

\section{Exosystem}

The exosystem represents social settings where a child's development is influenced by the environment that he or she is not a part of [7]. It represents the social networks of the parents such as workplaces, friends, extended-family members, and health and welfare services and their religious institutions [6]. Parents' social networks can support child caring and enhance children's development. Particularly in those cases, for example, where the parents' workplace provides good medical benefits, paid leave, and flexible working schedule, if friends and extended-family members give advice, companionship, and assistance, and if health and welfare services afford financial assistance [6].

\section{Macrosystem}

The macrosystem is the outermost layer of environmental context in ecological systems theory, representing the broader social influences such as laws, economic circumstances, and cultural and societal expectations [6]. In Act No. 20 of 2003 article 7, paragraph 1 parents have the right to participate in choosing educational units and obtain information about the development of their children's education. While paragraph [8] states, parents of children of compulsory age, are obliged to provide basic education to their children. Parental involvement in physical education can also be influenced by the belief system of the parents [4]. Ecology system theory suggests that a child's development is affected by the roles parents play in their educational experiences across environmental contexts (e.g., communication with teachers, giving assistance, affording physical activity participation). Therefore, this study explored the meaning of parental involvement from the perspectives of parents of children with developmental disabilities. We specifically sought to understand their experiences of involvement in PE, parents' roles, and partnerships between parents and physical education teachers.

\section{PARTICIPANT SELECTION}

Teachers of Physical Education and Sport were chosen by using sample criteria. The sample teachers were the teacher who had experienced the parents' participation.

The researcher was able to choose four teachers in the beginning, however only two teachers agreed to participate in this research. These two teachers were from Special Needs School (SKhN) 01 Serang. The pseudonym name was used to protect their identity and to ensure their anonymity. The teachers were chosen by the support of the principal of Special Needs School. The researcher contacted the principal to ask the permission so the researcher was able to share the objective of research with the teachers and to make the teachers were able to participate with the research.
The researcher then contacted the teachers who had the interest to discuss more about the research. The experience of the teachers was the main focus in this research. The requirements of the teachers were: a) had taught Physical Education and Sport lesson in Special Needs School. b) Had more than two years teaching experiences. Both teachers were Asep and Agus (pseudonym names)

1) Aseps' background: Asep is the teacher with black lighter-skinned, 41 years old, had 14 years experience teaching Physical Education and Sports. Asep, graduated as bachelor in Physical Education and Sports, started his career as Physical Education and Sports teacher in secondary school for 8 years. In 2011, he was promoted as a civil servant in Skh 01 Kota Serang, Banten Province. (Special Needs School). He had taught Physical Education and Sports lesson for different types of disability for 8 years (A, B, C, and D). During this research, he was teaching in grade 10,11 , and 12 .

2) Agus' background: Agus is the teacher with black lighter-skinned, 39 years old. He had 4 years experience teaching Physical Education and Sports lesson. He started his teaching career as a teacher in Special Needs School. Agus was the teacher of Physical Education and Sports lesson in SkH (Special Needs School) 01 Serang, Banten province. He has been teaching different types of disability for 8 years, (A, B, C, and D). During this research, he was teaching in grade 7, 8 , and 9 .

TABLE I. PARTICIPANT DEMOGRAPHIC INFORMATION

\begin{tabular}{|c|l|l|}
\hline & \multicolumn{1}{|c|}{ Name: Asep } & \multicolumn{1}{c|}{ Name: Agus } \\
\hline Sex & Male & Male \\
\hline Age & 41 years old & 39 years old \\
\hline Ethnic & Palembangnesse & Sundanese \\
\hline Degree & Bachelor & Bachelor \\
\hline Year of teaching & 2004 & 2014 \\
\hline $\begin{array}{l}\text { Years of teaching in } \\
\text { special need school }\end{array}$ & 2011 & 2014 \\
\hline
\end{tabular}

\section{B. Data Generation}

The research data was gathered using teacher's identity questionnaire, semi structured-interview, audio visual (photos and documentation), and research anecdote. To build the relationship with the research correspondents, the researcher visited the school where the participants working in order to held the informal meeting to introduce them to the research. The researcher provided the recruitment letter, agreement form, personal identity form, and interview guideline. The short brief about research objective and procedure was explained to the teachers. The interview schedule was also determined in this meeting.

\section{Demographic Information}

The researcher used the short identity questionnaire to identify the gender, age, ethnicity, education, the year of teaching in special need school, school characteristics (grade, teaching time allocation, name of school, type of disability) and furthermore to gather the detail description within the teachers. 
TABLE II. SCHOOL INFORMATION

\begin{tabular}{|c|c|c|}
\hline & Asep & Agus \\
\hline Grade & $10,11,12$ & $7,8,9$ \\
\hline Hours & 18 hours & 18 hours \\
\hline Days & 4 days & 4 days \\
\hline Name of school & SKhN 01 Kota Serang & SKhN 01 Kota Serang \\
\hline $\begin{array}{c}\text { Type of } \\
\text { disability }\end{array}$ & A, B, C, D & A, B, C, D \\
\hline
\end{tabular}

\section{Interviews}

Both Physical Education and Sports teachers completed two face-to-face interview sessions, each session was about 30-60 minutes length. The interview schedule was set in weekly interval, giving the participants opportunity to revisit the result of the first interview before the second interview. It allowed the researcher and participants to discuss about the first interview though. The interview guidelines were; a) describing the Physical Education and Sports learning b) describing the parents' participation in Physical Education and Sports learning c) the score of parents' participations in Physical Education and Sports learning d) the participants' experience in parent's participation in Physical Education and Sports learning and participants' role in parents-teacher meeting. e) The participants' relationship with parents of students with disability. Those four interview sessions were completed in a month. All interviews were recorded in audio and transcript. The interview transcripts were sent to participants through email, two days after the interview was done. The researcher then asked the participants to review the transcript to ensure the accuracy and to identify the error. During the second interview, the researcher discussed with the participants about problems from the first interview to present the accurate meaning, then the researcher and participant discus about the documents and photos that they showed in the interview session.

\section{E. Artifacts}

Those two PE teachers were asked to provide the documents, including school documents (Syllabus, daily lesson plan, meeting agenda, teacher's journal, and students' journal report) and photos. Those documents were copied by the teachers' permission to the data folder of researcher's laptop.

\section{F. Researcher's Journal}

The researcher wrote the journal after the interviews were done. This journal aimed to record the main findings from the interviews, to sort out some ideas in order to explore more about the upcoming interview.

\section{DATA ANALYSIS}

Both interview transcripts and researcher's journals were subjected to line-by-line thematic analysis [9]. The thematic analysis identifies the common structure of particular experience under study is primary mechanism by which understanding was achieved. [9]. It requires reading the interview transcript and researcher's journal numerous times. In particular, revealing phrases were highlighted and coded with meaningful labels. Codes that are conceptually similar were gathered together into thematic statements, giving fundamental meaning to the experiences [10]. Photos and documents were gathered to verify thematic statement. The data was analysed using these following procedures;

\section{A. The Interviews were Encoded Verbally}

The interview transcripts were interpreted numerous times to achieve comprehensive understanding on researcher's finding and to explore the important statement and phrases that associated to research questions on observation process and the sorted data that was highlighted, codes and categorization based on their similarity (values or perspective, parents' role, the relationship with parents, and Physical education and Sports learning process) and differentiated elements, words, and special phrases were categorized and organized to the early themes.

\section{B. Trustworthiness of Data}

The trustworthiness of preliminary study was gained using four criteria; Credibility, Transferability, Dependability, and Conformability [11]:

- Credibility was increased with data triangulation (data taken from teachers) and participant checked [12]. Second, teachers checked interview transcript for the accuracy in each interview sessions. The brief of thematic analysis was also sent to teachers to be reviewed and to ensure their experience was accurately recorded. Their transcript was also sent to them via email/WhatsApp messenger.

- Transferability was increased to describe teachers and school and used purpose sampling (maximum sampling strategy) [10].

- Dependability of findings were gathered using various data (interview transcript, audio visual, documents, and researcher's journal)

- Conformability was established through audit trial [13]. An audit track to ensure the external trial of research process.

TABLE III. CRITERIA FOR TRUSTWORTHINESS

\begin{tabular}{|c|l|}
\hline Trustworthiness Criteria & \multicolumn{1}{|c|}{ Application to the Preliminary Study } \\
\hline $\begin{array}{c}\text { Credibility or } \\
\text { Verification }\end{array}$ & $\begin{array}{l}\text { Data Triangulation } \\
\text { Male teachers } \\
\text { Member Checks } \\
\text { Interview transcripts }\end{array}$ \\
\hline \multirow{3}{*}{ Transferability } & $\begin{array}{l}\text { Thick Description } \\
\text { Participants' demographic information } \\
\text { Description of school and PE programs } \\
\text { purposeful sampling } \\
\text { Maximum variation sampling }\end{array}$ \\
\hline \multirow{2}{*}{ Dependability or } & $\begin{array}{l}\text { Multiple Data Sources } \\
\text { Interviews, visual artefacts, document, and } \\
\text { field notes }\end{array}$ \\
\hline Conformability & Audit Trail \\
\hline
\end{tabular}

\section{RESULTS}

It was a priceless process on understanding the teachers' interpretation toward parents' participation in physical 
necessity, parents' expectation, students' learning goal). Relating to students' active participation in learning, teachers could implement the specific purpose for each unit course and developing the effective learning strategy (e.g. behaviour management, learning modification, and modified teaching tools).

\section{CONCLUSIONS}

Three themes occurred as the result of the thematic analysis; (1) process was not assessed (2) supportive parents were not active (3) Physical education and sports learning process was the way to build the connection.

\section{REFERENCES}

[1] U. Bronfenbrenner, "The Ecology of Human Development: Experiments by Nature and Design. Cambridge," MA: Harvard University Press. 1979.

[2] M.D. Duerden, and P.A. Witt, "An ecological systems theory perspective on youth programming," Journal of Park and Recreation Administration, vol. 28(2), pp. 108-120, 2010.

[3] U. Bronfenbrenner, "Ecological systems theory. In R. Vasta (Ed.), Six theories of child development: Revised formulations and current issues,' pp. 187-249, London, PA: Jessica Kingsley, 1992.

[4] J.C. Sontag, "Toward a comprehensive theoretical framework for disability research: Bronfenbrenner revisited," The Journal of Special Education, vol. 30, pp.319-344, 1996.

[5] M.D. Duerden, and P.A. Witt, "An ecological systems theory perspective on youth programming," Journal of Park and Recreation Administration, vol. 28(2), pp. 108-120, 2010.

[6] L.E. Berk, "Child development (8th ed.)," Boston, MA: Allyn and Bacon, 2009.

[7] U. Bronfenbrenner, "Ecology of the family as a context for human development: Research perspectives," Developmental Psychology, vol. 22, pp. 723-742, 1986.

[8] Regulation of Minister of Education and Culture of the Republic of Indonesia Number 23, Year 2015 on Good Characters Development.

[9] M. van Manen, "Researching lived experience: Human science for an action sensitive pedagogy," London, ON: The Althouse Press, 1997.

[10] M.Q. Patton, "Qualitative research and evaluation methods (3rd ed.)," Thousand Oaks, CA: Sage, 2002.

[11] Y.S. Lincoln, and E.G. Guba, "Naturalistic inquiry," Newbury Park: Sage Publications. 1985.

[12] L.M. Meadow, and J.M. Morse, "Constructing evidence within the qualitative project. In J.M. Morse, J.M. Swanson, \& A.J. Kuzel (Eds.), The nature of qualitative evidence" (pp. 187-202). Thousand Oaks, CA: Sage. 2001.

[13] J.W. Creswell, "Qualitative inquiry and research design: Choosing among five traditions (2nd ed.), Thousand Oaks, CA: Sage. 2007. 